\title{
Construction Period Analysis of Composite Method Using Hollow-PC Column
}

\author{
Jaeyup KIM \\ Dept. of Architectural Engineering \\ Korea National University of Transportation \\ Chungju, Republic of Korea \\ e-mail: kimjy67@ut.ac.kr \\ Sooyeon SEO \\ Dept. of Architectural Engineering \\ Korea National University of Transportation \\ Chungju, Republic of Korea \\ e-mail: syseo@ut.ac.kr
}

\author{
Byeonghun PARK \\ Dept. of Architectural Engineering \\ Korea National University of Transportation \\ Chungju, Republic of Korea \\ e-mail: bbj4302@ut.ac.kr \\ Guncheol LEE \\ Dept. of Architectural Engineering \\ Korea National University of Transportation \\ Chungju, Republic of Korea \\ e-mail: gclee@ut.ac.kr
}

\begin{abstract}
Recently, as the problems such as lack of construction personnel and reduction of construction duration due to the increasing labor cost and aging labor personnel, the researches on the $\mathrm{PC}$ method have been reactivated. However, the purpose of most of these researches is to develop and structurally interpret the $\mathrm{PC}$ method, and there are not that many researches conducted from the perspective of the construction management. Accordingly, this research examines the composite method using hollow-PC column (hereinafter referred to as "HPC composite method") from the perspective of the construction management, and the purpose is to analyze the construction period of the HPC composite method. The differences per method are analyzed through the specific comparison of the construction procedures as well as the indepth interview with the expert, and the construction period of the HPC composite method is analyzed based on the analyzed differences. It seems that the construction In the HPC composite method, the construction period seems to vary depending on the column segment status. It seems that the construction period can be more effectively shortened through increasing the number of segmented columns. However, since the construction period relating to work types other than the PC method is not considered in this research, it is necessary to analyze the construction period relating to the overall construction process in the future.
\end{abstract}

Keywords-joint; hollow precast concrete column; head splice sleeve; PC composite method; half-PC slab method

\section{INTRODUCTION}

\section{A. Study Background and Purpose}

In Korea, as the precast concrete method (hereinafter referred to as "PC method") has been indicating problems such as lack of construction personnel and reduction of construction duration due to the increasing labor cost and aging labor personnel, the related researches have been reactivated [1]. In comparison to the preexisting reinforced concrete (hereinafter referred to as "RC method"), the PC method not only indicates difficulties in securing the integrity of the joint between the members, but also is vulnerable to the lateral force. In addition, due to the member transport cost as well as the lifting equipment use, it is difficult to reduce the construction cost [2]. Currently, a number of new methods are being developed to supplement such problems. The composite method using hollow precast concrete column (hereinafter referred to as "HPC composite method" is a method developed to supplement the weaknesses of the preexisting PC method. Some of the precedent researches on the HPC composite method are: a research on compressive behavior of HPC column [3], a research on structural performance of beam-column joint using HPC column [2], a research on structural performance of head splice sleeve [4], a research on performance evaluation through head splice sleeve-applied column [5], and a research on seismic performance of HPC column [6].

However, the purpose of most of the preexisting researches is to structurally interpret the member, and there are not that many researches conducted from the perspective of the construction management. Accordingly, this research examines the HPC composite method from the perspective of the construction management, and the purpose is to analyze the construction period of the HPC composite method. It is expected that the analysis of the construction period of the HPC composite method can be used as the reference data for applying the HPC composite method to the actual field in the future.

\section{B. Study Scope and Method}

In this research, the HPC composite method currently being developed is selected as the research subject, and the purpose is to analyze the construction period of the HPC composite method. The application scope of the HPC composite method is limited to warehouse facilities such as distribution centers, and the half-PC slab method which serves as the basis for the PC composite method is selected as the comparison subject.

To described the research method, initially, the 12 copies of data such as design drawing and construction plan are 
analyzed, and the specifics of the HPS composite methodbased joint are constructed. In addition, the construction procedures between the half-PC slab method and the HPC composite method are compared, and the differences per construction are analyzed through the in-depth interview conducted with the PC method expert. Based on the result acquired through analyzing the differences, the construction period is analyzed through setting up a hypothesis that the HPC composite method is applied to the case to which the half-PC slab method is applied.

\section{ANALYSis OF CONSTRUCTION PROCEDURES OF HPC COMPOSITE METHOD}

\section{A. Development of HPC Composite Method}

The HPC composite method is a structural system which applies the strengths of the RC/PC methods. The HPC column and head splice are used to enhance the joint-related construction performance and integrity. The HPC column is a composite HPC column composed of hollow precast concrete and cast-in-place [2]. The HPC column is manufactured through placing the rebar into the specially manufactured mold and using the centrifugal force. The rotation creates an empty space within the column, and, therefore, the PC serves as the mold. Through placing the concrete into the empty space, the integrity of the HPC column and half-PC beam can be enhanced.

The motar-filled splice sleeve (hereinafter referred to as "splice sleeve") is frequently used for the PC method-based joint. The head splice sleeve is a mortar-filled connection, and its adhesion is increased through mounting the head on the embedded bar [4]. The preexisting splice sleeve lacks constructability and economic feasibility due to its excessive cross section. However, the head splice sleeve indicates high constructability and economic feasibility since its cross section is optimized through increasing its adhesion. Figure 1 and Figure 2 show the HPC column as well as the cross section of the head splice sleeve.

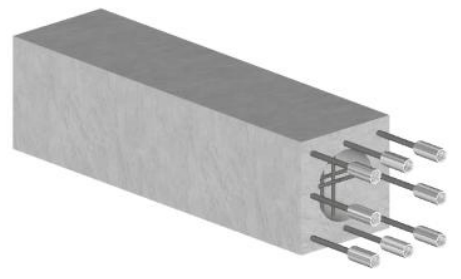

Figure 1. Hollow-PC column

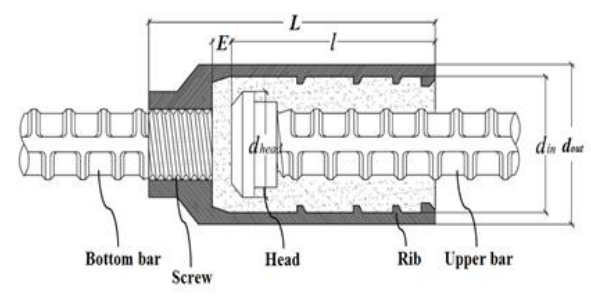

Figure 2. Head splice sleeve

\section{B. Specifics of HPC Composite Method-based Joint}

The HPC composite method uses the HPC column and head splice sleeve to create a joint in between the columns, and the process is quite different from that of the half-PC slab method. Table 1 shows the specifics of the joint created in between the columns through the HPC composite method. Initially, the half-PC beam and half-PC slab are installed on the HPC column. Starting from the hollow section of the HPC column, the topping concrete is placed into the beam and slab. After the concrete curing is complete, the upper column is jointed with the lower column. The column joint process is conducted in the following order: head splice sleeve combination, leveling and perpendicularity adjustment, column support fixation and placement of nonshrinkage mortar into sleeve. After the column joint process is complete, the mold is assembled in between the columns, and the concrete is placed into the hollow section until the height reaches $1 / 2$ the upper column.

TABLE I. SPECIFICS OF JOINT IN BETWEEN COLUMNS

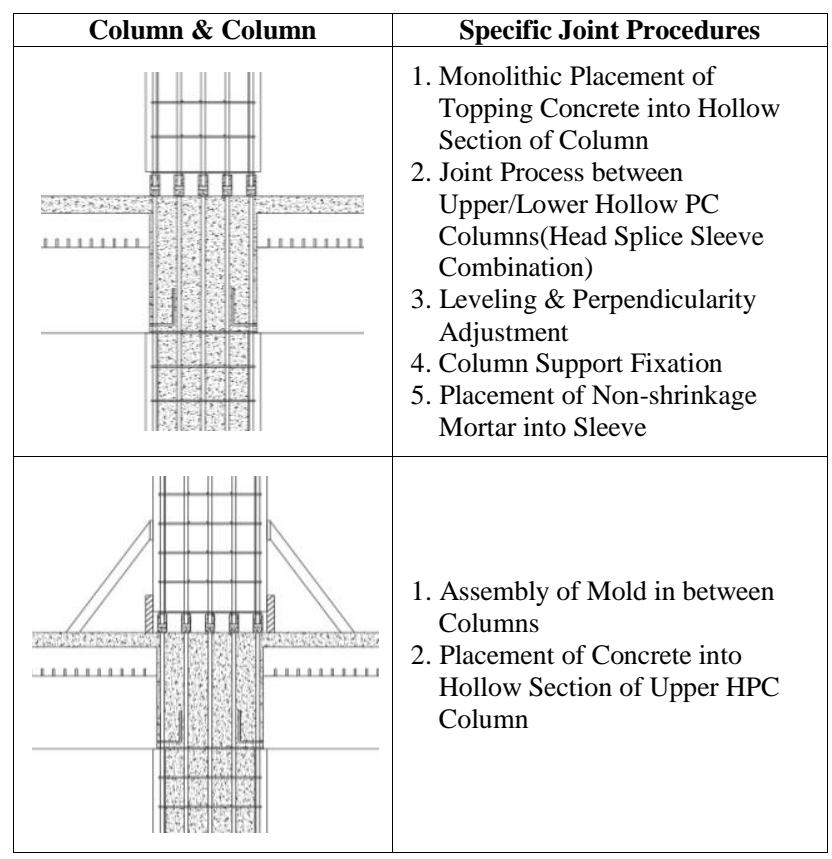

\section{Analysis on the Difference of HPC Composite Method}

(1) Comparison of Construction Procedures: The construction procedures between the HPC composite method and half-PC slab method are compared to analyze the differences. Table 2 shows the comparison of the construction procedures between the HPC composite method and half-PC slab method. In the HPC composite method, "assembly of mold in between columns" and "placement of non-shrinkage mortar into sleeve" are differently ordered in comparison to those ordered in the half-PC slab method, and "settlement of lower beam bar in hollow section" and "placement of concrete into hollow section of HPC column" are additionally included. 
TABLE II. COMPARISON OF CONSTRUCTION PROCEDURES

\begin{tabular}{|c|c|c|}
\hline & $\begin{array}{l}\text { Half-PC Slab } \\
\text { Method }\end{array}$ & $\begin{array}{l}\text { HPC Composite } \\
\text { Method }\end{array}$ \\
\hline $\begin{array}{c}\text { Basic } \\
\text { Installation }\end{array}$ & $\begin{array}{l}\text { - Marking } \\
\text { - Anchor Location Perforation } \\
\text { - Internal Hole Cleaning } \\
\text { - Anchor Bold Construction } \\
\text { - Level Confirmation \& Shim Plate } \\
\text { Installation }\end{array}$ & $\begin{array}{l}\text { - Marking } \\
\text { - Anchor Location Perforation } \\
\text { - Internal Hole Cleaning } \\
\text { - Head Splice Sleeve Construction } \\
\text { - Level Confirmation \& Shim Plate } \\
\text { Installation }\end{array}$ \\
\hline $\begin{array}{c}\text { Column } \\
\text { Installation }\end{array}$ & $\begin{array}{l}\text { - PC Column Erection } \\
\text { - Leveling \& Penpendicularity } \\
\text { Adjustment } \\
\text { - Support Fixation } \\
\text { - Assembly of Mold in between } \\
\text { Columns } \\
\text { - Placement of Non-shrinkage Mortar } \\
\text { into Sleeve }\end{array}$ & $\begin{array}{l}\text { - HPC Column Erection } \\
\text { - Leveling \& Penpendicularity } \\
\text { Adjustment } \\
\text { - Support Fixation } \\
\text { - Placement of Non-shrinkage Mortar } \\
\text { into Head Splice Sleeve } \\
\text { - Assembly of Mold in between } \\
\text { Columns } \\
\end{array}$ \\
\hline $\begin{array}{c}\text { Girder } \\
\text { Installation }\end{array}$ & $\begin{array}{l}\text { - Support Fixation after Girder } \\
\text { Installation }\end{array}$ & $\begin{array}{l}\text { - Support Fixation after Girder } \\
\text { Installation (Settlement of Hook- } \\
\text { shaped Lower Beam Bar in Hollow } \\
\text { Section) }\end{array}$ \\
\hline \begin{tabular}{|c|} 
Sleeve \\
Installation
\end{tabular} & $\begin{array}{l}\text { - Slab Installation } \\
\text { - Lower Support Fixation }\end{array}$ & $\begin{array}{l}\text { - Slab Installation } \\
\text { - Lower Support Fixation }\end{array}$ \\
\hline \begin{tabular}{|c|} 
Electric \\
Piping \& \\
Upper \\
Rebar \\
Placement \\
\end{tabular} & $\begin{array}{l}\text { - Slab-Slab Reinforcing Rebar } \\
\text { Placement } \\
\text { - Slab-Beam Reinforcing Rebar } \\
\text { Placement } \\
\text { - Upper Beam/Slab Rebar Placement }\end{array}$ & $\begin{array}{l}\text { - Slab-Slab Reinforcing Rebar } \\
\text { Placement } \\
\text { - Slab-Beam Reinforcing Rebar } \\
\text { Placement } \\
\text { - Upper Beam/Slab Rebar Placement }\end{array}$ \\
\hline $\begin{array}{c}\text { Concrete } \\
\text { Placement }\end{array}$ & $\begin{array}{l}\text { - Half-PC Beam, Half-Slab Monolithic } \\
\text { Placement }\end{array}$ & $\begin{array}{l}\text { - Hollow Section of HPC Column, } \\
\text { Half-PC Beam, Half-Slab Monolithic } \\
\text { Placement }\end{array}$ \\
\hline
\end{tabular}

(2) Analysis of Construction Period Differences: Based on the comparison of construction procedures, the construction period differences between the methods are analyzed through the interview with the expert. Table 3 shows the analyzed construction period differences between the half-PC slab method and HPC composite method. As a result, the HPC composite method uses different member joint method, lifting work, and concrete placement, and, therefore, indicates different construction period. Since the weight of the HPC columns is light in comparison to that of the preexisting PC column, the column segment count can be decreased. The daily column-related lifting work load varies depending on the column segment, and this may shorten or extend the construction period.

TABLE III. CONSTRUCTION PERIOD DIFFERENCES PER METHOD

\begin{tabular}{|c|l|l|}
\hline & \multicolumn{1}{|c|}{$\begin{array}{c}\text { Half-PC Slab } \\
\text { Method }\end{array}$} & \multicolumn{1}{c|}{$\begin{array}{c}\text { HPC Composite } \\
\text { Method }\end{array}$} \\
\hline $\begin{array}{c}\text { Member } \\
\text { Joint } \\
\text { Method }\end{array}$ & Use of Preexisting Splice Sleeve & Use of Head Splice Sleeve \\
\hline $\begin{array}{c}\text { Lifting } \\
\text { Work }\end{array}$ & $\begin{array}{l}\text { Increased Lifting Work Load Due } \\
\text { to Column Segment }\end{array}$ & $\begin{array}{l}\text { Decreased Lifting Work Load Due } \\
\text { to Minimized Column Segment }\end{array}$ \\
\hline $\begin{array}{c}\text { Concrete } \\
\text { Placement }\end{array}$ & $\begin{array}{l}\text { Monolithic Placement of Girder, } \\
\text { Slab \& Column }\end{array}$ & $\begin{array}{l}\text { Addition of Hollow Section } \\
\text { Placement }\end{array}$ \\
\hline
\end{tabular}

\section{CONSTRUCTION PERIOD ANALYSIS OF HPC COMPOSITE METHOD}

\section{A. Analysis Method}

The differences in the HPC composite method are analyzed in order to analyze the construction period of the HPC composite method. Based on the deducted differences, the construction period is analyzed through setting up a hypothesis that the HPC composite method is applied to the case to which the half-PC slab method is actually applied. Table 4 shows the outline of the case to which the half-PC slab method is applied. The PC method is applied to this building from the 1st basement floor to the 5th upper floor. The identical PC is used for all the columns and girders. More than three methods are partially and compositely applied to the slab. In particular, the segmented columns are used due to the maximum transport weight of the lifting equipment.

TABLE IV. The CASE OF CONSTRUCtion PC METHOD

\begin{tabular}{|c|l|}
\hline Title of the project & Seoul distribution complex development \\
\hline Building site & Songpa-gu, Seoul \\
\hline Principal use & Distribution center \\
\hline Kind of the project & New construction \\
\hline Total floor area & $404,346.81 \mathrm{~m}^{2}$ \\
\hline Building area & $84,018.92 \mathrm{~m}^{2}$ \\
\hline Number of stories & $\mathrm{B} 2 \sim 7 \mathrm{~F}$ \\
\hline Column & PC Column \\
\hline Girder & PC Girder \\
\hline Slab & DECK Slab, PC Slab (DTS, RPS) \\
\hline
\end{tabular}

\section{B. Construction Period Analysis of HPC Composite Method}

The HPC composite method uses different member joint method, lifting work, and concrete placement, and, therefore, indicates different construction period. However, since the member joint method and concrete placement are barely different, only the lifting work is considered into the analysis of the construction period.

(1) Construction Period of Selected Case: The construction period of the selected case is analyzed through using the 1st 2nd floors and 3rd floor as the standards. This building is constructed through the use of the segmented heavy weight columns. The columns used for the 1st 2nd floors are segmented twice, and, therefore, 3 segmented columns are used as 1 column. The columns used for the 3 rd floor are segmented once, and, therefore, 2 segmented columns are used as 1 column. The daily average quantity of the members assembled into this building is 15 for segmented column, 17 for girder and 20 for slab. The construction period per floor used as the standard is as shown in Table 5. 


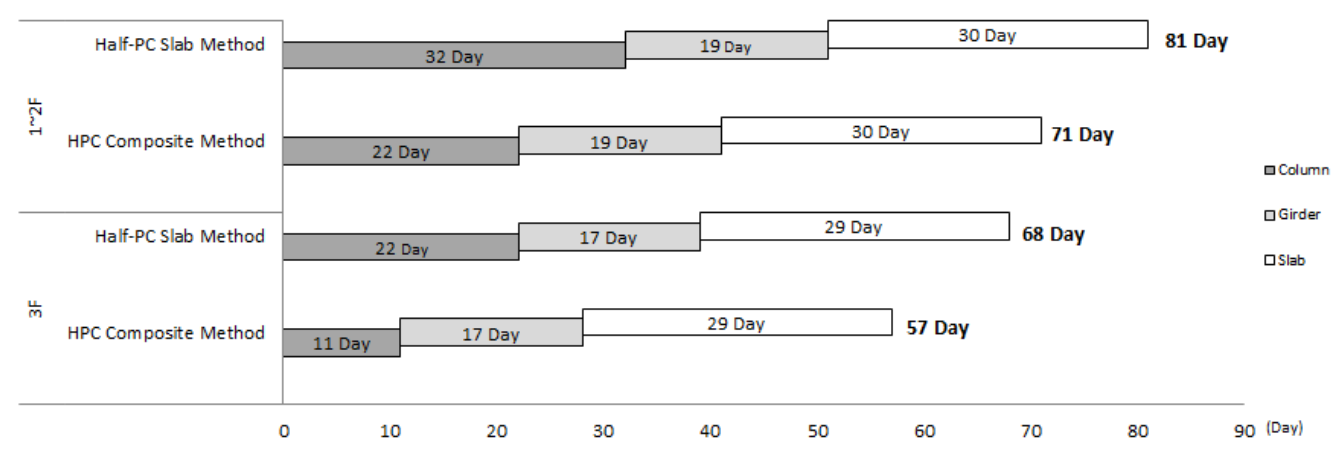

Figure 3. Construction period analysis of HPC composite method

(2) Analysis of Construction Period of HPC Composite Method : The total quantity of the segmented columns used for the $1 \mathrm{st} \sim 2$ nd floors is 481 . Provided that this is replaced with the HPC columns indicating a 50\% hollow ratio, the total quantity of the segmented columns can be reduced to approximately 320 . In addition, the daily average quantity of the segmented columns assembled into the building is 15 , and the HPC composite method-based column installation period is 22 days. This shows that the installation period can be shortened by approximately 10 days. In addition, the total quantity of the segmented columns used for the 3rd floor is 320 , and the installation period can be shortened by approximately 11 days. Figure 3 shows the analyzed construction period of the HPC composite method. The construction period for the 1st 2nd floors is shortened by $12.35 \%$, and the construction period for the 3rd floor is shortened by $16.18 \%$.

TABLE V. ANALysis of CONSTRUCtion Period of SELECTED CASE

\begin{tabular}{|c|c|c|c|c|}
\hline \multicolumn{2}{|r|}{ Division } & $\begin{array}{c}\text { Total } \\
\text { Quantity }\end{array}$ & $\begin{array}{c}\text { 1Day } \\
\text { Quantity }\end{array}$ & Period(Day) \\
\hline \multirow{4}{*}{$1 \sim 2 F$} & $\begin{array}{c}\text { Segmented } \\
\text { Column }(\text { Column })\end{array}$ & $481(160)$ & $15(5)$ & 32 \\
\hline & Girder & 314 & 17 & 19 \\
\hline & Slab & 585 & 20 & 30 \\
\hline & \multicolumn{3}{|c|}{ Total Construction Period } & 81 \\
\hline \multirow{4}{*}{$3 \mathbf{F}$} & $\begin{array}{c}\text { Segmented } \\
\text { Column(Column) } \\
\end{array}$ & $320(160)$ & $15(7.5)$ & 22 \\
\hline & Girder & 580 & 17 & 17 \\
\hline & Slab & 574 & 20 & 29 \\
\hline & \multicolumn{3}{|c|}{ Total Construction Period } & 68 \\
\hline
\end{tabular}

\section{CONCLUSION}

It is difficult to decrease the construction cost through using the preexisting PC method since the high capacity lifting equipment used for transporting the heavy weighted members increases the transport cost. Currently, a number of new methods are being developed to supplement such problem. The HPC composite method is one of the methods being developed to supplement the weakness of the preexisting PC method. However, there are not that many researches conducted from the perspective of the construction management. Accordingly, this research is conducted on the HPC composite method from the perspective of the construction management, and the purpose is to analyze the construction period of the HPC composite method. The important results deducted from this research are as follows.

In order to analyze the differences in the HPC composite method, the construction procedures are compared and the interview is conducted with the expert. In the HPC composite method, "assembly of mold in between columns" and "placement of non-shrinkage mortar into sleeve" are differently ordered in comparison to those ordered in the half-PC slab method, and "settlement of lower beam bar in hollow section" and "placement of concrete into hollow section of HPC column" are additionally included.

In addition, the HPC composite method uses different member joint method, lifting work, and concrete placement, and, therefore, indicates different construction period. Based on the differences in the HPC composite method, the construction period is analyzed through setting up a hypothesis that the HPC composite method is applied to the case to which the half-PC slab method is actually applied. As a result, it is found that the HPC composite method decreases the column segment count, and, thereby, shortens the construction period.

In the HPC composite method, the construction period seems to vary depending on the column segment status. It seems that the construction period can be more effectively shortened through increasing the number of segmented columns. However, since the construction period relating to work types other than the PC method is not considered in this research, it is necessary to analyze the construction period relating to the overall construction process in the future.

\section{ACKNOWLEDGMENT}

This work was supported by the Human Resource Training Program for Regional Innovation and Creativity through the Ministry of Education and National Research Foundation of Korea (NRF-2015H1C1A1035953).

\section{REFERENCES}

[1] SH An, UK Lee, and KI Kang. "A Study on the Proposal about the Improvement of PC in Construction Industry". Journal of The Korea Institute of Building Construction. Seoul. Korea, Vol. 20(7), pp. 13340, July 2004.

[2] DH Sin, Structural Capacity of the Exterior Beam-Column Joint Using Hollow Precast Concrete Column, Master's thesis, Korea National University of Transportation, 2016. 
[3] SJ Lee, A Compressive Behavior of Hollow Precast Concrete Column, Master's thesis, Korea National University of Transportation, 2014.

[4] BR Nam, Structural Capacity of Mortar-filled Head Splice Sleeve, Master's thesis, Korea National University of Transportation, 2016.

[5] SG Kim, Development and Application of Head-Splice Sleeve for Mechanical Connection of Reinforcements, Dissertation, Korea National University of Transportation, 2016.
[6] WY Lim, HG Park and CS Kim "A Study on the Proposal about the Improvement of PC in Construction Industry", Journal of The Korea Concrete Institute, vol. 26, pp. 35-46, February 2014.

[7] Korea precast prestressed concrete association, Precast concrete. Seoul, Kimoondang, 2007 